JOURNAL OF SECURITY AND SUSTAINABILITY ISSUES

ISSN 2029-7017 print/ISSN 2029-7025 online

2022 Volume 12

http://doi.org/10.47459/jssi.2022.12.2

\title{
CHANGES AND TRANSFORMATIONS OF WARS AND ARMED CONFLICTS. THEORETICAL APPROACH
}

\author{
Waldemar Krztoń \\ Faculty of Management, Ignacy Eukasiewicz Rzeszów University of Technology, \\ Powstańców Warszawy 12 35-959 Rzeszów, Poland \\ E-mail:wkrzton@prz.edu.pl
}

Received 10 December 2021; accepted 3 February 2022; published 1 March 2022

\begin{abstract}
Wars and armed conflicts have accompanied mankind from the beginning of history and belong to the category of social phenomena. They became a permanent part of the historical process and are changing with it. Throughout history, wars have changed, as have views on the phenomenon of war, on war theories and strategic concepts. These views were and are a derivative of the progress of civilization. Since the turn of the 20th and 21 st centuries, societies and nations have been the cause and target of wars to the larger extent than countries. Territory and power are no longer the primary causes and goals of armed conflicts. The analysis of these changes allows us to call these phenomena "new wars". The article presents the issues of changes and transformations of wars and armed conflicts. It was stated that defining war as a political act was no longer sufficient. It was also established that in a changing world, new forms of war existed and would continue to emerge. The classic war, however, is not yet gone.
\end{abstract}

Keywords: security; civilization; armed conflict; new wars; peace, war

Reference to this paper should be made as follows: Krztoń, W. 2022. Changes and transformations of wars and armed conflicts. Theoretical approach. Journal of Security and Sustainability Issues, 12, 17-26. http://doi.org/10.47459/jssi.2022.12.2

JEL Classifications: R1

\section{Introduction}

Wars and armed conflicts have accompanied mankind from the beginning of history and belong to the category of social phenomena. They became a permanent part of the historical process and are changing with it. Over the years, wars as well as views on the phenomenon of war, on war theories and strategic concepts have changed. Wars were and are a derivative of the progress of civilization. The problem of war is still present and the paths leading to peace are varied. One of them certainly leads through the scientific understanding of this phenomenon. War has been a subject of scientific interest for a long time. It has been and is one of the most dealt with problems over the centuries. The understanding of war and the meaning of the concept itself continue to evolve and undergo new analyzes.

The aim of the research was to analyze the changes and transformations of modern wars and armed conflicts. On the basis of the aim of the research, the author defined the research problem in the form of the question: What does the changing image of war in the contemporary world look like? In the scientific knowledge of the subject of war, the research apparatus of social sciences was used, due to the fact that war is a social phenomenon, it concerns man, and, in fact, societies. The method of analysis and synthesis was used. The analysis of the content of the studied problems allowed for the breakdown of scientific problems into parts and the study of each of them separately. On the other hand, the synthesis combined these elements into a new whole. This allowed for the formulation of general conclusions on the basis of partial theses. The analysis of the literature on the subject shows 
that the essence of the classical war is disappearing and defining it as a political act is insufficient. The next element in the research process conducted by the author was the development of the hypothesis. With regard to the research problem and the analysis of the literature, the following working hypothesis was formulated: in a changing world, new forms of war occur and will appear. The classic war, however, will not disappear for a long time.

\section{The understanding of war in modern times}

The understanding of war and the meaning of the concept itself continue to evolve and undergo new analyzes. Albert Einstein notes that "as long as there is man in the world, there will also be wars (Einstein, 1947)." According to many scholars, the man is such a universal cause that has been repeated in all epochs. The sources of wars in man should be found both in the weaknesses of human nature, the behavior of each person as well as in his individual characteristics (Table 1). Mariusz Fryc in the book Wojna. Współczesne oblicze states that "War is a human activity, hence, in order to exist - it must first be born in the minds of people (Fryc, 2009, p.p. 47)". Therefore, when analyzing the sources of war, it is obligatory to mention the human motives that have always guided people throughout history as well as pushed them to various deeds, including war. These are: selfishness, thoughtlessness, weakness, tendency to aggression and the quest for domination.

Table 1. The causes of wars in different periods of human social development

\begin{tabular}{|l|c|c|}
\hline \multicolumn{1}{|c|}{ Cause } & Author & Age \\
\hline Insatiable human desires & Cicero & I BC \\
\hline Biological features and human nature & Titus Maccius Plautus & III-II BC \\
\hline Characteristics of great people - leaders & Paul Holbach & XVIII \\
\hline Competition, distrust, lust for fame & Tomasz Hobbes & XVIII \\
\hline Intergroup conflicts & Sigmund Freud & XX \\
\hline A clash of civilizations & Samuel P. Huntington & XX \\
\hline Rivalry between political groups - hostile intentions & Raymond Aron & XX \\
\hline
\end{tabular}

Own study

War always required justifications: "war [...] is never justified by itself, it is always fought in the name of a future peace that must be established or restored (Hassner, 2002, p. p. 149) "- peace is an absolute, obvious and universally recognized value. Hannah Arendt aptly put it when she said "the goal of war is peace, but the question what is the goal of peace has no answer. Peace is an absolute thing (Arendt, 1993, p.p. 105)". Aristotle had already spoken in this tone. He emphasized that wars and conquests were not the goal of the state, but only a means to peace, just as work was a means of leisure and an action was to meditate. Saint Augustine highly appreciated peace and identified it with God's gift, the main idea, the goal which should be pursued. On the other hand, he treated war as an exception to peace but believed that it was a means leading to peace. In contrast, Raymond Aron was of the opinion that war was disgusting (Aron, 1994, p. p. 121)". However, the above-mentioned thoughts have not been shared by everyone throughout history. Beginning with Heraclitus, who argued that polemos is the father of all things, through Hegel, Nietsche, Max Scheler, there were many thinkers who perceived the superiority of war over reconciliation. Nevertheless, war is not a value in itself, but rather a means to defend the value of peace.

The 21st century is characterized by new ways of shaping security, completely different natures of wars and conflicts, and different from the current ways, as well as methods of building and maintaining peace. A new reality is being born before our eyes, leading to the asking of fundamental questions relating to war. The possibility of wars also arises in a new way. New, small, asymmetric, modern, informational, cybernetic, virtual, mediated, hybrid and creeping wars have been waged recently. These wars are very different from those of the past (Czupryński, 2021).

Analyzing war is hard to separate from the current civilization and cultural challenges, widespread for the entire society. Wars of the future have already begun. Their characteristic features could be discerned in the recent 
armed conflicts. Scholars point out that most modern wars are conflicts that do not involve states and their armed forces. Therefore, the essence of classical warfare is fading away. Also the statement that the war is a continuation of politics does not correspond to the present times. "Over the last decades, the war has gradually and imperceptibly changed its character. The classic war waged by states, which still largely marked the course of the Cold War rivalry, seems to be consigned to history. States abdciated as actual monopolists of wars, and their place is being taken more and more frequently by parastatal structures and private players (Münkler, 2004, p.p. 7)”.

The nature of armed conflicts has also changed in modern times. The conflicts became more local, with a civilization, ethnic or religious background. The parties to the current conflicts are more and more often terrorists, organized crime groups, paramilitary units, mercenary units, groups of local warlords, and separatists (Krztoń, 2021, p.p. 76-77). They are usually internal, sudden and full of violence and lawlessness. There also occurred asymmetric conflicts. The asymmetry results not only from the disproportion of forces, but also from the opponent's distinctness. The opponent is often not a subject of international law, has no territory, and is not limited by any legal or moral norms.

In the so-called "post-Clausewitzian" world, the main tenets of Clausewitz's theory, that is, of war as a political tool and a rational means of achieving political goals have been challenged. The growing importance of local conflicts of low-intensity, the disappearance of war as an instrument of policy making, and the increase in the value of asymmetric wars have become a fact. It was also noted that (Wiatr, 1982, p. p 349):

1) total nuclear war between superpowers is no longer a rational means and therefore cannot be rationally fought and won;

2) a non-nuclear war between superpowers (equipped with powerful nuclear arsenals) is unlikely and cannot be considered a rational alternative to nuclear war;

3) local wars between powers without nuclear arsenals or limited-range wars involving conventional weapons are possible and are in fact fought but their ability to rationally serve political goals is severely limited by the possibility of nuclear escalation.

While emphasizing the specificity of new wars, Herfried Münkler, professor of political science, proposes to consider three processes of change (Münkler, 2004, p. 10):

- firstly, the de-nationalization or privatization of acts of war. It was possible because direct warfare became relatively inexpensive;

- secondly, the asymmetry of war violence, i.e. a situation in which unequal opponents usually fight each other. There are no more fronts and, therefore, skirmishes occur only seldom and great battles almost never;

- thirdly, the gradual independence or autonomization of forms of violence, previously subordinated to military requirements. As a consequence, the regular armies lost control over the course of military operations.

It is not states but societies and nations that have become to a large extent the reason and purpose of wars since the 1990s of the twentieth century. Territory and power are no longer the primary causes and targets of armed conflict. The analysis of these changes allows us to call these phenomena "new wars". Herfield Münkler concludes that "So many different factors interact in the emergence of new wars. Neither of the reasons can be considered fundamental and decisive. This impenetrable tangle of various motives and causes, which gives no hope of concluding peace, is primarily a simple consequence of the fact that it is not states that fight in new wars, but parastatal entities (Münkler, 2004, p. 16-17”. Contemporary armed conflicts and wars are mostly fought by societies and nations, which may be caused by ethnic, national and religious stimuli. Any member of a community or nation may possibly and actually be a fighter. The tools of war are individual weapons, home-made bombs, "passenger planes" (September 11, 2001. in the United States), as well as everyday equipment used for war purposes, an example is the "machete" (Rwanda) or "hoe" (Cambodia) (Loś, Regina-Zacharski, 2010, p.p 193). Note that the most shocking and effective attack in recent years was carried out using non-military tools against non-military targets. In a way, we are returning to the original situation, when wars were waged by the entire society and not only by their separate structures. Professor Stanisław Koziej states: "We are returning anew to the oldest, classical theory of wars. This is the final victory of Sun-Tzy over Clausewitz (Koziej, 2008, p.p. 23)". 
At the same time, there is also a transfer of conflicts and wars to the cyber sphere. Many analysts watch for a concentration of military activity in this area in the future (Sanger, 2021). The world today is moving towards the "Third Wave" information age, as the Tofflers put it, "Third Wave countries sell information to the world, as well as innovation, management methods, culture and mass culture, modern technologies, financial services and much, much more." One of these services may be military protection, based on the best armed forces of the Third Wave countries (Toffler, 2006, p.p. 30".

There is also a change in the concept of achieving the general goal of the war, which is to abandon the complete destruction of the enemy, in favour of excluding only militarily significant objects. Therefore, more and more frequently the war will be waged in the area of information in the cyberspace environment. In the face of that, human consciousness will become a battleground in an even greater dimension than before. Information warfare is conducted primarily in order to shape the social awareness of the opponent and one's own society. Information is not only a message, it also becomes a weapon in the fight against an opponent or a potential threat (Fig. 1).

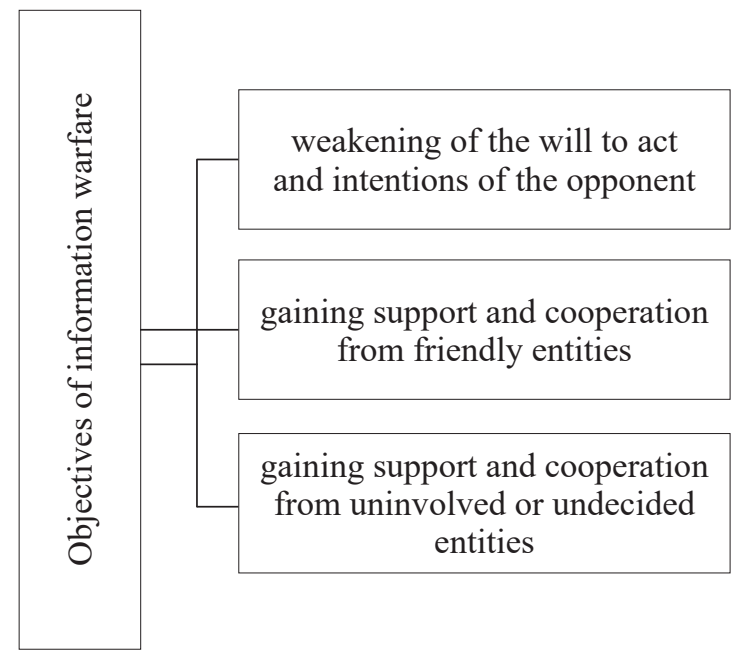

Picture 1. Objectives of information warfare

Source: own study

The information struggle is also known as the "struggle for hearts and minds." Information in contemporary conflicts is of increasing importance, and public opinion in democratic countries turns out to be the key to success. Napoleon said: "Victory alone does not mean anything, you have to be able to use it (Napoleon)." And today, victories often cannot be used without public support. Thus, the human consciousness will become a battlefield to an even greater extent than before, it is not enough to defeat the opponent, one should also strive to convince the community directly and indirectly involved in the conflict to be right.

\section{Changes and transformations of wars and armed conflicts}

The French social philosopher Pierre Hassner considers "duality" to be the main feature of modern wars. When describing the modern world, he shows two trends that have a clear impact on it. They are (Hassner, 2002, p. p. 62-63):

1) the trend of changes of a universal and unifying nature;

2) a differentiating and particularizing trend, leading to an increase in self-awareness and a sense of separateness among different ethnic groups.

By presenting the shape of new wars, Hassner places them in the post-colonial world. He proposes to juxtapose the term "barbarian" with the person of "bourgeoisie", personifying the wars of the "West" (Hassner, 2002, 
p.p. 57). He sees the contemporary world be split into two parts: wealthy and modernizing, and also poor, subject to stagnation or even degeneration. The scientist observes the formation of two extremely different "classes": global, using the achievements of the modern world, and aglobal, deprived of access to it. These two "classes" can mix but not integrate. The differences are especially visible in the contemporary wars that are waged. On the one hand, there are poorly armed and most often disorganized fighters, and on the other hand, there are mercenaries, employees of Western concerns, representatives of humanitarian organizations, observers of international intervention forces, etc.

Many authors, when noticing the above phenomenon, give it the term "asymmetrization of war", stating that contemporary conflicts are not a clash of equal opponents. Thus, the weaker party is pushed to use different methods, techniques and tools to minimize the domination of the other party. Such asymmetric measures include techniques of guerrilla warfare and terrorism. It does not matter whether the dominant party murders the civilian population with a machete or destroys the enemy with surgical precision with unmanned weapons. The common element is the fact that there is no symmetry of the opposing forces (Münkler, 2004, p.p. 39-45).

An interesting typology of changes taking place in contemporary wars in a new approach is presented by Steven Metz and James Kievitt. In their opinion, the following factors influence the nature of the modern battlefield (Metz, Kievit, 1995): (1) the growing importance of non-war operations (humanitarian interventions, peacekeeping missions, anti-partisan operations) and asymmetric military operations; (2) blurring the distinction between war and peace, enemy ally; (3) the growing tendency of multi-level involvement of the civilian population, forcing the ability to cooperate and coordinate the activities of the army with civilians and non-military organizations; (4) technological changes enabling precise, remote attacks conducted by well-disguised and virtually elusive combat assets; (5) spatial expansion of the battlefield, with the emerging prospect of moving the fight into a completely new, informational dimension; (6) the unprecedented increase in the importance and efficiency of command, control and information gathering systems; (7) striving to minimize own losses, but also losses among the civilian population, and even the losses of the enemy, and the growing importance of non-lethal combat measures.

Modern wars are called new wars but the novelty is not in one essential part, but in their unique combination. Piotr Chmielarz describes wars as a mixture of old and new solutions, presenting them in three groups (Chmielarz, 2010, p.p. 296):

1) the old ones, the nature of which has remained relatively unchanged over the past few decades. This category includes factors such as the existence of nuclear weapons or guerrilla wars;

2) new ones that appeared for the first time in history in the last twenty years. We can classify here the field of war technology, which is based on advanced information and computer solutions, the phenomenon of globalization, especially in the sphere of economics, and the special role of public opinion;

3) old-new, which influenced military activity in quite distant past (several hundred years ago), then their importance substantially weakened, and their revival has been observed recently. A good example of this category of phenomena is the loss of monopoly on the use of armed violence by states and the privatization of military activities.

A remarkable division of modern wars is presented by Professor Henryk Hermann. He believes that in the second half of the twentieth century, there were only a few "full-scale" wars, while the "half-size" wars, also referred to as armed conflicts or local wars, prevailed. Other terms "intermediate war, unarmed war, unconventional war" were also used. Henryk Hermann considers such wars to be full-fledged in which at least two countries (coalitions) take part, engaging the maximum possible potential to conduct them, publicize their goals and observe the norms of international law. In historiography, this type of war is also called state wars and their basic feature is indicated: symmetry (Hermann, 2006, p.p. 36".

British General Rupert Smith in the book The Przydatność sity militarnej. Sztuka wojenna we wspótczesnym świecie states that the paradigm of industrial warfare between states has been replaced by a new one, wars among societies. Reflections on this problem constitute the background of his book. In "war among societies" 
there is no separate battlefield waged between opponents, but more and more frequantly there is no military force, at least on one side of the conflict. According to the author, "The war among societies has a different character - it is about a situation in which the battlefield is the people themselves - passers-by or residents virtually everyone and everywhere. Military operations can take place anywhere: in the presence of civilians, against civilians, in defense of civilians. The civilian population becomes an object that must be defeated just like the enemy (Smith, 2010, p.p. 24)". Contemporary war is no longer so clear military activity conducted on a large scale and aimed at an unequivocal political settlement. This is the result of a radical change in the relationship between the political and military systems. These factors constantly interpenetrate and mix. When analyzing contemporary wars, the transforming and interacting environments of politics and military should be understood. Only this method of thinking leads to the perception of war today.

War among societies is characterized by important factors such as (Smith, 2010, p.p. 40): (1) the fight is no longer conducted for clearly defined, absolute goals characteristic of industrial wars between states, but for less explicit goals important to non-state actors; (2) the struggle takes place among the societies, which further strengthens the involvement of the media. The battlefield is housing all over the world, but also streets and villages in conflict zones; (3) conflicts do not fit within clear time frames, as the participants of the fight strive to achieve a condition that could be sustained until the final agreement is reached. This may take years or even decades; (4) the fight is no longer fought with the maximum involvement of forces and it is not about achieving the goal at any cost. Fighters try to save their strength; (5) Every opportunity is used to find new uses for old weapons. Weapons, designed to be used on the battlefield against soldiers equipped with heavy equipment, are adapted to the needs of modern conflicts because tools designed for industrial wars are often unsuitable for wars among societies; (6) the parties to these wars are mostly non-state entities. Conflicts and confrontations involve multinational forces in alliances or coalitions whose opponents are groups without state status.

The theory of "four generation wars", which appeared in the late 1980s of the last century, has gained a lot of popularity recently. The theory has its critics, but regardless of its different assessment, it is worth bringing it closer. According to William S. Lind, the creator of this concept, in the evolition of the nature of the conflicts, after the signing of the Peace of Westphalia in 1648, which ended the Thirty Years' War, four generations of wars can be distinguished (Lind, 2004 ):

1) the first, which was characterized by a professional army, a strict hierarchy in command, battles carried out with the use of cannons and muskets and, above all, tactics of lines and columns. Its greatest heyday was to occur in the Napoleonic Wars;

2) the second, which was dominated by mass firepower (artillery conquers, infantry occupies), its peak was the First World War;

3) the third, the maneuvering war (German Blitzkrieg), which was distinguished by firepower, speed and surprise, is symbolized by World War II;

4) the fourth, the war is decentralized, themodern enemy has no territory, he can attack anywhere in the world.

According to Andrzej Polak, the wars of the first generation were to be based on the mass of living force, and the next generation - on the mass of fire. Maneuverability was to be a feature of the third generation wars, and the asymmetry - of the fourth generation (Polak, 2012, p.p. 42). In the fourth generation wars, unlike the wars known from history, the supporters of the theory notice quite clear modifications of goals (leading to political paralysis in the state and international organizations) and the means and methods used (the use of new technologies, large-scale terror) (Balcerowicz, 2013, p.p. 177).

Among the "new wars" also stand out "hybrid wars", which are a mixture of several concepts of their predecessors - "new wars, wars among societies, wars of four generations, information warfare". According to Frank G. Hoffman, a supporter of this theory, hybrid war is characterized by "physical and psychological, kinetic and non-kinetic [...] convergence between fighters and civilians [...] of armed forces and communities, states and non-state actors, as well as combat systems with which they are equipped (Hoffman, 2009, p.p. 34)". The basis of the concept was the assumption that contemporary conflicts are very complex. They also include inadequate elements that create a hybrid. In the Universal Dictionary of the Polish Language, we can read that a hybrid is 
"a creation [...] consisting of various mismatched elements; a hybrid of genetically different species (Dubisz, 2003, p.p. 66)". In turn, according to Artur Gruszczak, a feature of the hybrid nature of modern wars is the coexistence of two basic levels of conflict (Gruszczak, 2011, p.p. 14): (1) territorial - referring to the classically understood national state and traditional ethnic, clan or tribal communities permanently inhabiting a given territory; (2) virtual, having a cross-territorial, cross-border network structure enabling communication within a given network, global promotion of values, ideas and principles as well as maintaining and recreating its own structure. It should be remembered that the comprehensive use of all available means and methods in combat, regardless of their diversity, has always been the norm of the art of war.

In 2014, the annexation of Crimea by Russia led to an escalation of violence, which turned into a permanent and brutal conflict with an unprecedented characteristic described by some experts on the subject as "creeping war" (Korniejenko, 2014). A creeping war is a "strange" war in which one of the parties to the conflict (the aggressor) prefers to remain unrecognizable, although the international community knows who it represents. The crawling war has no beginning or end, not only the regular army fights in it, the attackers remain anonymous and have no signs of national affiliation. It is non-linear, seemingly devoid of a plan, point, and is characterized by the lack of legal rules. It introduces chaos and disinformation, leaves behind a lasting reluctance and awareness of harm. It is characterized by a fait accompli strategy and ambiguity. The essence of this strategy is the assumption that the more surprising and bold moves that are carried out, the sooner the international community will get used to it and will not be opposed to the actions carried out. On the other hand, ambiguity should not be understood as inconsistency or unpredictability. Because, contrary to appearances, the activities carried out are based on a precise plan and a clearly defined goal (Zapałowski, 2021). On the one hand, unmarked mercenaries are sent to soldiers and civilians who become their victims, but at the same time non-violence and conduct talks are proposed. The fights are conducted by regular military units, but also by volunteers, special forces, mercenaries and separatists. The rebels (green men) are well trained, have modern weapons, command and communication systems, which allow them to effectively fight regular military units. They operate efficiently, inciting point conflicts that are difficult to control by the regular armed forces. This strange war can go on for years, triggering a spiral of hatred, injustice and a sense of permanent tension. The authors of this form of war are the Russians and it is practically waged with the Ukrainian state.

\section{Conclusions}

Most of modern wars are conflicts, the target of which will not be states and their armed forces. They have been replaced by parastatal structures. Terrorists, organized crime groups, paramilitary units, mercenary units, groups of local warlords and separatists are the parties to the conflicts more and more frequently. Thus, the essence of classical warfare is disappearing and defining it as a political act is insufficient. The 21 st century is characterized by new and different natures of war and conflict. The possibility of the emergence of wars is also arranged in a new way, and their conduct will be significantly different from those known from the past. The danger of the outbreak of a global war has been taken by conflicts of various kinds, which break out and persist in various parts of the world. The wars of the 21 st century will be hard to separate from the civilization and cultural challenges common to the entire nascent information society. The political reality of the information age will be complex, while the dichotomous division of political relations "peace-war" is insufficient. On the verge of war and peace, a new character of political relations has emerged - an intermediate state, which is characterized by the nature of confrontation and the means used are unconventional. This new state is called a kind of war, and at the same time is inconsistent with the recognized understanding of war.

The most common stimulus for future feuds will be ethnic, national and religious conflicts. To a large extent, societies and nations will become the source and target of wars. We can already see a clear predominance of internal conflicts and wars, which gradually internationalize and pose a serious threat, not only to a given country and its neighbours, but also to the entire region. There is an exacerbation of ethnic, national and religious conflicts and tensions. Future conflicts will not be clashes of equal opponents. Asymmetric conflicts will appear (Table 2). The asymmetry will result not only from the disproportion of forces, but also from the opponent's otherness. Thus, the weaker party will be pushed to use different methods, techniques and tools to minimize 
the domination of the other party. On the other hand, technological changes will enable precise, remote attacks carried out by well-disguised and virtually elusive combat means. The division between war and peace, enemy and ally, will also blur.

Table 2. Differences between classical and asymmetric warfare

\begin{tabular}{|c|c|l|}
\hline Criterion & \multicolumn{1}{|c|}{ Classic wars } & \multicolumn{1}{c|}{ Asymmetric wars } \\
\hline Participants & National armies, alliances, coalitions & $\begin{array}{l}\text { Paramilitary groups, organized criminal groups, mercenaries, parts of } \\
\text { national armies }\end{array}$ \\
\hline Objectives & National or allied interests & Gaining identity, ethnic, religious \\
\hline $\begin{array}{c}\text { Way of waging } \\
\text { war }\end{array}$ & $\begin{array}{c}\text { Hierarchical command, great } \\
\text { importance of battles and operations, } \\
\text { advanced military technology }\end{array}$ & $\begin{array}{l}\text { Scattered, fragmented, directed against the civilian population, atrocities: } \\
\text { rape, hunger, use of light weapons and mines of own construction }\end{array}$ \\
\hline External support & Alliances, coalitions, powers & Diaspora, transnational mafia, mercenaries, regional forces \\
\hline
\end{tabular}

Source: own study

There are many indications that the war will be waged in a decentralized manner, the enemy will have no territory, and will be able to attack anywhere in the world. A feature of wars will be the coexistence of two basic levels of conflict: territorial - referring to the classically understood national state and its territory, and virtual, having an extraterritorial cross-border network structure enabling communication within a given network. The opponent will often not be subject to international law and will not be limited by any legal or moral norms. It is, therefore, quite difficult to clearly define the shape of the future war and its form, as it will be a constantly evolving model, changing its properties along with the changes taking place in the political, economic, social, technical and cultural spheres. For Western countries, war should be limited, predictable, and low loss-making. On the other hand, the other side will strive for a total, long, unpredictable and bloody war.

Each new war can determine new trends and outline new features that have not existed before. Contemporary wars and armed conflicts are accompanied by changes in which:

1) information becomes a strategic weapon and an important instrument of war;

2) there is no clear, marked opponent (armed forces);

3) the activities of the smallest groups (platoon, squads and even individual soldiers) are gaining in importance;

4) the opponent often does not have a formal organizational structure or a permanent form of organization of activities;

5) the opponent takes advantage of every favourable circumstance and form of attacking;

6) wars and conflicts become long-lasting and cause personal losses, which is not accepted by society;

7) the war is becoming more and more networked and shapeless.

War changes and will keep changing, but its transformations are generally of an evolutionary, not revolutionary nature. These transformations are rarely radical in nature, much more often it is the modernization of its components resulting from the socio-military situation at a given moment in history.

Modern times, contrary to the attitude and opinions of the believers supporting the illusion of the world without wars, teem with different kinds of conflicts, including wars. Military actions concerning war in Ukraine-Russia conflict (2014-) made people aware that war might be real. It may concern every society to a greater or lesser extent. Although methods, means and space of leading a fight have changed, war may still belong to the present and it should be remembered. 


\section{References}

Arendt H. (1993). Macht und Gewalt, München.

Aron R. (1994). Pokój i wojna między narodami (Peace and war between nations), Warsaw.

Balcerowicz B. (2013). O pokoju. O wojnie. Miedzy esejem a traktatem (About peace. About the war. Between essay and treatise), Warsaw.

Chmielarz P. (2010), Wojna a państwo (War and the state), Warsaw.

Czupryński A. (2021). Peace and armed conflict studies. Journal of Security and Sustainability, Volume 11, https://doi.org/10.47459/ jssi.2021.11.3

Dubisz S. (2003). Uniwersalny słownik języka polskiego (Universal dictionary of the Polish language), Warsaw, vol. 2.

Einstein A. (1947). https://www.manhattanrarebooks.com/pages/books/2187/albert-einstein-philippe-halsman/albert-einstein-silver-gelatin-print-photograph $(09 / 10 / 2021)$

Fryc M. (2009). Wojna. Wspótczesne oblicze (War. Contemporary face), Torun.

Gruszczak A. (2011). Hybrydowość wspótczesnych wojen - analiza krytyczna (Hybridity of modern wars - critical analysis), [in:] Biblioteka BBN: Asymetria i hybrydowość - stare armie wobec nowych konfliktów (Asymmetry and hybridization - old armies in the face of new conflicts), Warsaw.

Hassner P. (2002). Koniec pewników, eseje o wojnie, pokoju i przemocy (End of certainties, essays on war, peace and violence), Warsaw.

Hermann H. (2006). Przeobrażenia wojen drugiej połowy XX stulecia, [in:] K. Olejnik (red.), Wojna jako przedmiot badań historycznych (War as a subject of historical Research), Torun.

Hoffman F.G. (2009). Hybrid Warfare and Challenges. Joint Force Quarterly, 52, pp. 34 https://smallwarsjournal.com/documents/ jfqhoffman.pdf (5/03/2021).

Korniejenko A. (2014). Pelzająca wojna (The creeping war), Kraków.

Koziej S. (2008). Między piektem a rajem. Szare bezpieczeństwo na progu XXI wieku (Between hell and paradise. Gray security at the threshold of the 21st century), Torun.

Krztoń W. (2021). Wojna jako problem bezpieczeństwa wspótczesnego świata (War as a security problem in the contemporary world), Rzeszów.

Lind W.S. Understanding Fourth Generation War, https:/original.antiwar.com/lind/2004/01/15/understanding-fourthgeneration-war/ $(20 / 07 / 2021)$.

Łoś R., Regina-Zacharski J. (2010). Współczesne konflikty zbrojne (Contemporary armed conflicts), Warsaw.

Münkler H. (2004). Wojny naszych czasów (The wars of our time), Kraków.

Metz S., Kievit J. (1995). Strategy and the Revolution in Military Affairs, from Theory to Policy, Strategic Studies Institute, US Army War College, Carlisle Barracks, Pennsylvania 17013-5050, June 1995, https:/www.files.ethz.ch/isn/109773/Startegy_Revolution_Military_Affairs.pdf (08/15/2021)

Napoleon B. http://www.cytaty.info/autor/napoleonbonaparte-2.htm (02/20/2021).

Polak A. (2012). Zmienny charakter współczesnych konfliktów zbrojnych (The changing nature of contemporary armed conflicts) [in:] M. Huzarski, A. Czupryński (ed.), Wojna i pokój przedmiotem badań polemologiczno-irenologicznych (War and peace as a subject of polemological andrenological Research), Warszw.

Sanger D.E. (2021). Cyberbroń - broń doskonała. Wojny, akty terroryzmu i zarządzanie strachem w epoce komputerów (Cyber weapons - the perfect weapon. Wars, acts of terrorism and fear management in the age of computers), Gliwice.

Smith R. (2010). Przydatność sity militarnej. Sztuka wojenna we wspótczesnym świecie (Usefulness of military strength. The art of war in the modern world), Warsaw.

Toffler A., Toffler H. (2006). Wojna i antywojna. Jak przetrwać na progu XXI wieku? (War and anti-war. How to survive on the threshold 
JOURNAL OF SECURITY AND SUSTAINABILITY ISSUES

ISSN 2029-7017 print/ISSN 2029-7025 online

of the 21st century?), Poznań.

Wiatr J. (1982). Socjologia wojny w postclausewitzowskim świecie (The sociology of war in the post-Clausewitz world), Warsaw.

Zapałowski A. (2021). Generowanie przemożnej sity. Morale, uzbrojenie, organizacja, doktryna. Filozofia i elementy składowe sity bojowej (Generating overwhelming strength. Morale, armament, organization, doctrine. Philosophy and components of combat strength) [in:] P. Plebaniak (ed.), Sun Zi i jego sztuka wojny. Filozofia i praktyka oddziaływania na bieg zdarzeń, Kraków.

Waldemar KRZTON - PhD in the field of social sciences in the discipline of defense science. A research and teaching worker at the Faculty of Management at Ignacy Łukasiewicz Rzeszów University of Technology. He is the author of many scientific publications. He specializes in research on the problems of war and armed conflicts in historical, contemporary and prognostic terms, in the history of wars and information security in cyberspace.

ORCID ID: 0000-0001-8292-4327 